\title{
Implikasi Yuridis Pembacaan dan Penandatanganan Akta Risalah e-RUPS yang Dibuat oleh Notaris
}

\author{
Ninik Alfiyah ${ }^{1 凶}$, Mohammad Saleh $^{2}$ \\ 1, 2 Magister Kenotariatan Fakultas Hukum Universitas Narotama Surabaya, Indonesia \\ E-mail Korespondensi: ninikalfiyah11@gmail.com
}

\begin{abstract}
The rapid development of information technology has been responded to positively by the Indonesian government for a long time, especially in organizing an electronic GMS, as regulated in Article 77 of Law Number 40 of 2007 concerning Limited Liability Companies. Guidelines for implementing e-GMS were only issued in 2020 because the Covid-19 pandemic threatens the economy and/or the stability of the country's financial system, this provision is in the form of POJK Number 16/POJK.04 / 2020. In Article 12 of the POJK, the implementation of e-GMS is obliged to be made in the form of a notary deed. This raises problems regarding the procedures for reading and signing deeds that cannot be done electronically because they are considered contrary to the Civil Code, the Law on Notary Position, and the ITE Law. The purpose of this research is to analyze the legal basis for the implementation of e-GMS and the minutes of the meeting and the legal consequences of reading and signing the e-GMS Notarial Deed electronically. This study uses a normative juridical research method. The results of the study explain that if the notary reads and signs the $e$-GMS deed electronically, it will have implications for the evidentiary power of the deed, which is equivalent to the letter under the bill because no regulation explicitly gives the notary authority in that field, so the advice given is e. RUPS can be conducted electronically, however, the minutes of the meeting are made by the minutes of the meeting, and a copy is given to a notary so that the deed is in the form of a deed of partij and not a deed of relaas.
\end{abstract}

Keywords: legal implications, reading and signing of the deed, e-GMS

\begin{abstract}
Abstrak
Perkembangan teknologi informasi yang pesat telah direspon secara positif oleh pemerintah Indonesia sejak lama, khususnya dalam penyelenggaraan RUPS elektronik, isebagaimana diaturi dalami Pasali 77 UndangUndangi Nomori 40 Tahuni 2007 tentangi Perseroan Terbatas. Pedoman pelaksanaan e-RUPS baru diterbitkan pada tahun 2020 karena pandemi Covid-19 mengancam perekonomianidan/atau stabilitas sistem ikeuangan negara, ketentuan ini berupa POJK iNomor 16/POJK.04/2020. Pada pasal 12 POJK tersebut, pelaksanaan ie-RUPS iwajib idibuat idalam ibentuk iakta inotaris. Hal ini menimbulkan persoalan mengenai tata cara ipembacaan dan ipenandatanganan akta yang tidak dapat dilakukan secara elektronik karena dianggap bertentangan idengan KUHPerdata, Undang-Undang tentang Jabatan Notaris dan Undang-Undang ITE. Tujuan penelitian ini adalah untuk menganalisis terkait landasan hukum pelaksanaan e-RUPS beserta risalah rapatnya dan akibat hukum pembacaan dan penandatanganan Akta Notariil e-RUPS secara Elektronik. Penelitian ini menggunakan metode penelitian yuridis normatif. Hasil penelitian menjelaskan bahwa apabila notaris membacakan dan melakukan penandatanganan akta e-RUPS secara elektronik, berimplikasi pada ikekuatan pembuktian akta tersebut yaitu setara dengan surat di bawah itangan, karena belum ada regulasi yang secara eksplisit memberikan kewenangan notaris dalam bidang tersebut, sehingga saran yang diberikan e-RUPS dapat dilakukan secara elektronik akan tetapi mengenai risalahnya dibuat oleh notulen rapat dan salinannya diberikan kepada notaris, sehingga akta yang dibuat berbentuk akta partij dan bukan akta relaas.
\end{abstract}

Kata kunci: Implikasi Yuridis, Pembacaan dan Penandatangan Akta, e-RUPS

\section{Pendahuluan}

Perkembangan teknologi semakin hari semakin meningkat baik di bidang teknologi informasi, pendidikan, perdagangan ekonomi, hingga pelayanan publik baik pemerintah maupun nonpemerintah. Adanya teknologi informasi memberikan kemudahan baik 
Kosmik Hukum Vol. 21 No. 2 (2021): 105-114

E-ISSN: 2655-9242 | P-ISSN: 1411-9781

DOI: $10.30595 /$ kosmikhukum.v21i2.10283

perseorangan ataupun badan usaha dalam melaksanakan kegiatannya dengan mudah dan praktis, sehingga segala yang dijalankan dapat berjalan secara efektif dan efesien. Saranaprasana untuk menunjang pesatnya teknologi telah banyak disediakan baik dari bentuk media penyimpanan elektronik, internet yang memudahkan komunikasi dua atau multi arah dalam berbagai bentuk perangkat dan aplikasi, bahkan pembuatan dokumen secara elektronik telah diakomodir dengan jelasnya.

Keberadaan teknologi informasi khususnya mengenai data atau dokumen elektronik telah disadari sejak lampau oleh pemerintah Indonesia melalui penyimpanan data perusahaan secara elektronik. Guna memberikan kepastian hukum bagi penyimpanan dokumen perusahaan tersebut, pemerintah mengeluarkan regulasi berupa Undang-Undang Nomor 8 Tahun 1997 tentang Dokumen Perusahaan (UU Dokumen Perusahaan). Selain itu, terdapat regulasi lain yaitu Undang-Undang Nomor 40 Tahun 2007 tentang Perseroan Terbatas (UUPT) yang memberikan kemudahan bagi pemegang saham untuk mengadakan Rapat Umum Pemegang Saham (RUPS) secara daring (online) melalui video conference, teleconference, atau media elektronik lain dan memberikan kemudahan untuk membuat risalah RUPS baik dibuat secara fisik maupun elektronik. Dan selanjutnya, yang berkaitan dengan dokumen elektronik beserta kepastian hukumnya dikuatkan kembali dengan dikeluarkannya Undang-Undang Nomor 11 Tahun 2008 tentang Informasi dan Transaksi Elektronik (UU ITE) beserta Perubahannya.

Berdasarkan regulasi diatas, yang menjadi poin utama untuk dikaji selanjutnya yaitu mengenai ketentuan pelaksanaan RUPS yang dapat dilakukan secara elektronik (e-RUPS) beserta risalah rapatnya. Hal tersebut diatur dalam ketentuan Pasal 77 ayat (1) yang membahas mengenai legalitas pelaksanaan RUPS daring (online) dan ayat (4) yang memuat ketentuan bahwa "Setiap penyelenggaran RUPS sebagaimana pada ayat (1) harus dibuatkan risalah rapat yang disetujui dan ditandatangani oleh semua peserta RUPS".

Menurut Andi Prajitno', Pasal 77 UUPT memperkenankan pembuatan risalah rapat RUPS dibuat secara notariil akta atau akta dibawah tangan (onderhand acta). Pernyataan tersebut didasarkan pada penjelasan Pasal 77, bahwa yang dimaksud dengan "disetujui dan ditandatangani" adalah disetujui dan ditandatangani secara fisik atau secara elektronik. Untuk RUPS yang dibuat dibawah tangan diperbolehkan mengikuti rapat secara daring (online) tanpa hadir secara fisik di tempat rapat, memberikan pendapat dan menyatakan setuju atau tidak setuju. ${ }^{2}$ Sedangkan risalah rapat yang dibuat dalam bentuk akta notariil yaitu dibuat oleh dan dibacakan oleh noatis secara daring (online), saat ini masih menimbulkan polemik hukum.

Ketentuan Pasal 77 ayat (4) memberikan peluang bagi Notaris untuk membuat risalah rapat dalam bentuk notariil. Hal tersebut diperkuat dengan regulasi terbaru yaitu POJK Nomor 16/POJK.04/2020 Pasal 12 (1) tentang Pelaksanaan Rapat Umum Pemegang Saham Perusahaan Terbuka Secara Elektronik, yang berbunyi : "Risalah RUPS secara elektronik wajib dibuat dalam bentuk akta notariil oleh notaris yang terdaftar di Otoritas Jasa Keuangan....".

Akan tetapi dalam ketentuan pasal 5 ayat (4) huruf a UU ITE mengecualikan akta notaris sebagai bagian dari dokumen elektronik. Larangan pembuatan akta notariil secara elektronik diperkuat kembali dengan ketentuan Pasal 16 ayat (1) huruf m Undang-Undang Nomor 2 tahun 2014 tentang Perubahan Undang-Undang Nomor 30 Tahun 2004 tentang Jabatan Notaris (UUJN) yang menyatakan bahwa notaris wajib membacakan akta dihadapan penghadap dan ditandangani secara fisik oleh penghadap, saksi-saksi dan Notaris. Penggunaan kata menghadap, berhadapan, dan hadapan dalam UUJN merupakan terjemahan dari kata verschijnen yang berarti datang menghadap yang dimaksud dalam artian yuridis adalah kehadiran nyata. ${ }^{3}$

\footnotetext{
A.A. Andi Prajitno, Pengetahuan Praktis Tentang Apa dan Siapa Notaris di Indonesia sesuai UUJN Nomor 2 Tahun 2014, (Surabaya : Putra Media Nusantara, 2018), 85. 
Adanya aturan hukum yang saling bertentangan, akan berakibat pada jalannya e-RUPS dan risalah rapat yang ingin dibuat secara otentik. Apalagi implementasi e-RUPS sangat dianjurkan, karena Indonesia saat ini masih dalam masa pandemi covid-19 yang mengharuskan untuk physical distancing dan dalam rangka menghadapi ancaman yang membahayakan perekonomian nasional dan/atau stabilitas sistem keuangan. Maka sangat penting bagi notaris maupun selaku penyelenggara e-RUPS untuk mengetahui mengenai aturan pembacaan dan penandatanganan akta Risalah e-RUPS, agar tidak menimbulkan akibat hukum yang serius dan merugikan para pihak.

Penelitian ini juga merujuk pada penelitian-penelitian terdahulu yang mempunyai keterkaitan dengan isu hukum yang dibahas oleh penulis, penelitian-penelitian tersebut yaitu : Pertama, "Penyelenggaraan RUPS melalui Media Elektronik terkait Kewajiban Notaris Melekatkan Sidik Jari Penghadap". ${ }^{4}$ Perbedaan dengan penelitian penulis adalah lingkup pembahasan lebih menekankan pada permasalahan wajib tidaknya notaris dalam melekatkan sidik jari penghadap dalam akta yang berkaitan dengan RUPS yang diselenggarakan secara elektronik, sedangkan dalam penelitian ini, pembahasan lebih fokus ke akibat hukum pembacaan dan penandatangan Akta e-RUPS yang dibuat oleh notaris beserta landasan hukumnya dan tidak ada kaitannya dengan pengaplikasian sidik jari pada akta e-RUPS. Persamaan diantara penelitian yaitu membahas terkait penyelenggaraan e-RUPS beserta risalah aktanya. Kedua, "Akta Otentik Rapat Umum Pemegang Saham (RUPS) Melalui Media Telekonferensi (Mekanisme Pembuatan Dan Kekuatan Pembuktiannya)". ${ }^{5}$ Perbedaannya yaitu pembahasan lebih fokus pada mekanisme pembuatan akta beserta kekuatan pembuktian akta RUPS yang dibuat melalui media telekonferensi, sedangkan penelitian penulis lebih memfokuskan pada implikasi yuridis pembacaan dan penandatanganan secara elektronik pada akta risalah e-RUPS dengan mengkaitkan antara regulasi yang satu dengan yang lainnya khususnya pada aturan POJK Nomor 16/POJK.04/2020 yang tidak disinggung dalam penelitian tersebut. Persamaanya yaitu keduanya membahas mengenai Akta RUPS yang dibuat notaris berdasarkan media telekonferensi beserta dasar hukumnya.

\section{Rumusan Masalah}

Berdasarkan isu hukum di atas, terdapat 2 (dua) rumusan masalah yang akan dikaji dalam penelitian ini, sebagai berikut:

1. Apakah landasan hukum pelaksanaan e-RUPS dan risalah rapatnya ?

2. Bagaimana akibat hukum pembacaan dan penandatanganan Akta Notariil e-RUPS secara Elektronik?

\section{Metode Penelitian}

Metode penelitian yang digunakan dalam penelitian ini adalah yuridis normatif dengan pendekatan perundang-undangan dan pendekatan konseptual. Bahan hukum primer yang digunakan untuk menelaahh isu hukum ini yaitu Undang-Undang Nomor 40 Tahun 2007 tentang Perseroan Terbatas, Undang-Undang Nomor 2 Tahun 2014 tentang Perubahan Undang-Undang Nomor 30 Tahun 2004 tentang Jabatan Notaris, UndangUndang Nomor 11 Tahun 2008 tentang Informasi dan Transaksi Elektronik beserta Perubahannya, POJK Nomor 16/POJK.04/2020 Tahun 2020 tentang Pelaksanaan Rapat Umum Pemegang Saham Perusahaan Terbuka Secara Elektronik. Sedangkan bahan hukum sekunder yaitu berdasarkan teori-teori, konsep-konsep, literatur dan jurnal hukum yang berkaitan dengan isu atau permasalahan hukum yang dibahas dalam penelitian ini. Penulisan ini diawali dengan membuat kerangka kerja, kemudian mencari dan mengumpulkan

\footnotetext{
Amelia Sri Kusuma Dewi, “Penyelenggaraan RUPS melalui Media Elektronik terkait Kewajiban Notaris Melekatkan Sidik Jari Penghadap", Jurnal Arena Hukum, Vol. 8 No. 1 (2015), 108-126.

5 Wardani Rizkianti, "Akta Otentik Rapat Umum Pemegang Saham (RUPS) Melalui Media Telekonferensi (Mekanisme Pembuatan Dan Kekuatan Pembuktiannya)", Jurnal Yuridis, Vol. 3 No. 1 (2016), 84-98.
} 
Kosmik Hukum Vol. 21 No. 2 (2021): 105-114

E-ISSN: 2655-9242 | P-ISSN: 1411-9781

DOI: $10.30595 /$ kosmikhukum.v21i2.10283

bahan-bahan hukum. Bahan hukum yang telah terkumpul diklasifikasikan, kemudian disusun secara sistematis. Selanjutnya dilakukan analisis terhadap bahan hukum yang relevan dengan topik dalam penelitian ini. Berdasarkan bahan hukum yang telah ditinjau dan dianalisis, selanjutnya diuraikan dalam pembahasan untuk dapat ditarik sebuah kesimpulan.

\section{Hasil dan Pembahasan}

\section{Kewenangan Notaris dalam Membuat Akta}

Pasal 1 angka (1) UUJN, menerangkan bahwa "Notaris merupakan pejabat umum yang berwenang untuk membuat akta otentik dan kewenangan lainnya sebagaimana dimaksud dalam undang-undang ini atau berdasarkan undang-undang lainnya". Sedangkan pengertian dari akta otentik sendiri dijelaskan dalam ketentuan pasal 1868 KUHPerdata yang berbunyi : "suatu akta yang di dalam bentuk yang ditentukan oleh undang-undang, dibuat atau di hadapan pegawai-pegawai umum yang berkuasa untuk itu di tempat di mana akta itu diibuatnya". Akta otentik yang dibuat oleh atau dihadapan notaris selanjutnya disebut sebagai akta notaris yang bentuk dan tata cara pembuatannya ditetapkan dalam UUJN.

Akta notaris sebagai akta otentik mempunyai kekuatan hukum dengan jaminan kepastian hukum sebagai alat bukti tulisan yang sempurna (volledig bewijs), tidak memerlukan tambahan alat pembuktian lain dan hakim terikat karenanya. ${ }^{6}$ Atas dasar itulah, maka notaris dalam menjalankan jabatannya harus berprinsip pada asas kehatihatian, UUJN, dan Kode etik notaris agar tidak merugikan pihak yang memiliki kepentingan dengan akta tersebut. Untuk itu, notaris harus paham terlebih dahulu mengenai kewenangannya sebagaimana diatur dalam ketentuan pasal 15 ayat (1), ayat (2) dan ayat (3) UUJN. Wewenang notaris pada pasal 15 yaitu: Ayat (1):

"notaris berwenang membuat akta otentik mengenai semua perbuatan, perjanjian, dan penetapan yang diharuskan oleh peraturan perundang-undangan dan/atau yang dikehendaki oleh yang berkepentingan untuk dinyatakan dalam akta otentik, menjamin kepastian tanggal pembuatan akta, menyimpan akta, semuanya itu sepanjang pembuatan akta-akta itu tidak juga Ayat (2): ditugaskan atau dikecualikan kepada pejabat lain yang ditetapkan oleh undang-undang."

a. "mengesahkan tanda tangan dan menetapkan kepastian tanggal surat dibawah tangan dengan mendaftardalam buku khusus."

b. "membukukan surat di bawah tangan dengan mendaftar dalam buku khusus."

c. "membuat kopi dari asli surat di bawahtangan berupa salinan yang memuaturaian sebagaimana ditulis dan digambarkan dalam surat yang bersangkutan."

d. "melakukan pengesahan kecocokan fotokopi dengan surat aslinya."

e. "memberikan penyuluhan hukum sehubungan dengan pembuatan akta."

f. "membuat akta yang berkaitan denganpertanahan atau"

Ayat (3) :

g. "membuat akta risalah lelang."

"Selain kewenangan sebagaimanadimaksud pada Ayat (1) dan Ayat (2), notarismempunyai kewenangan lain yang diatur dalam peraturan perundang-undangan."

Berdasarkan kewenangan notaris dalam UUJN dan pengertian akta otentik pada pasal 1868 KUHPerdata, notaris dapat membuat 2 (dua) bentuk akta notariil, yaitu akta Partij dan akta Relaas. ${ }^{7}$ Akta Partij atau disebut sebagai akta pihak, yaitu akta yang dibuat dihadapan notaris, yang berisi tentang uraian atau keterangan, pernyataan para pihak yang diberikan atau diceritakan kepada notaris agar keterangannya tersebut dituangkan ke dalam bentuk akta autentik. Eka Sumarningsih menyebut akta partij atau akta pihak yaitu "akta yang dibuat di hadapan notaris, artinya akta yang dibuat berdasarkan keterangan atau perbuatan pihak yang menghadap notaris dan keterangan atau perbuatan itu agar dikonstantir oleh 
notaris untuk dibuatkan akta". ${ }^{8}$ Berdasarkan uraian diatas maka, dapat disimpulkan bahwa notaris hanya mengkonstantir kehendak para pihak dalam akta. Hal ini sejalan dengan Yurisprudensi dari Mahkamah Agung tertanggal 05 September 1973 Nomor 702K/Sip/1973 yang kaidah hukumnya berbunyi sebagai berikut:

"Notaris fungsinya hanya mencatatkan atau menuliskan apa-apa yang dikehendaki dan dikemukakakn oleh para pihak yang menghadap notaris tersebut. Tidak ada kewajiban bagi notaris untuk menyelidiki secara materiil apa-apa yang dikemukakan oleh penghadap di hadapan notaris tersebut."

Sedangkan Akta Relaas adalah akta yang dibuat oleh notaris atau disebut juga Akta Berita Acara yang berisi uraian dari notaris tentang apa yang dilihat dan disaksikan notaris sendiri atas permintaan para pihak, agar tindakan atau perbuatan yang dilakukan para pihak dituangkan ke dalam bentuk akta autentik, misalnya akta notaris yang dibuat dalam RUPS suatu Perseroan Terbatas.

Akta risalah rapat atau lebih dikenal dengan akta berita acara rapat (Relaas Acta) dapat dibuat secara notariil dan di bawah tangan. Akta ini berbeda dengan akta pihak (Partij Acta) yang merelatir kehendak para pihak, tetapi mencatat segala peristiwa yang dilihat didengar dan dirasakan dari pelaksanaan jalannya rapat atau acara yang diliput. Untuk Berita Acara Rapat (Relaas Acta) dari suatu badan hukum maupun nonbadan hukum, dapat dibuat dengan 2 (dua) cara, yaitu: ${ }^{9}$

Cara Pertama : Notaris dapat terlibat langsung dalam acara rapat, artinya Notaris hadir dalam rapat tersebut untuk merekam, menuangkan tulisan dalam akta dari apa yang dilihat, apa yang didengar dan apa yang diputuskan oleh mereka yang hadir dalam rapat atau acara tersebut atas permintaan pihak yang berkepentingan atau kuasanya. Dalam pembuatan akta seperti ini seorang notaris dituntut bersikap proaktif dan mempunyai inisiatif serta ketelitian yang sangat tinggi. Akta tersebut tidak harus ditandangani oleh seluruh peserta rapat, hanya yang perlu diingat apabila ada peserta rapat yang tidak bersedia menandatangani, maka hal ini Notaris wajib menulis sebab/alasan mengapa tidak bersedia menandatangani akta tesebut.

Cara Kedua : Notaris menerima penyerahan Notulen Rapat yang disebut Pengambilan/Pernyataan Keputusan Rapat (PKR) yang disebut di bawah tangan dan telah disahkan oleh Pimpinan Rapat sesuai dengan UUPT yang berlaku dari kuasanya (akta sepihak) untuk disalin dalam akta otentik.

G.H.S Lumban Tobing ${ }^{10}$ membedakan antara akta partij dan akta relaas. Pada akta partij, undang-undang mengharuskan adanya penandatanganan oleh para pihak, dengan ancaman kehilangan otentitasnya atau hanya mempunyai kekuatan pembuktian sebagai akta di bawah tangan. Setidak-tidaknya notaris mencantumkan keterangan alasan tidak ditandatanganinya akta oleh salah satu pihak pada akhir akta. Sedangkan pada akta relaas, tidak menjadi persoalan terhadap orang-orang yang hadir menandatangani akta atau tidak, akta tersebut masih sah sebagai alat pembuktian.

\section{Landasan Hukum Pelaksanaan e-RUPS dan Risalah Rapatnya}

Hikmah adanya pandemi Covid-19 berdampak pada sikap responsif Otoritas Jasa Keuangan (OJK) untuk segera membentuk regulasi terkait penyelenggaraan RUPS secara elektronik (e-RUPS) berupa POJK No. 16/POJK.04/2020. Alhasil, meskipun investor pemegang saham tidak hadir, mereka dapat menyelenggarakan RUPS secara sah. Direktur Evaluasi BEI I Gede Nyoman Yetna mengatakan POJK telah menyelesaikan satu dari dua tugas penting terkait e-RUPS, yakni ketersediaan regulasi dan infrastruktur teknis yang digunakan.

Berdasarkan Pasal 77 ayat (1) UUPT dan Pasal 1 angka (3) POJK Nomor 16/POJK.04/2020, e-RUPS merupakan pelaksanaan RUPS oleh Perusahaan Terbuka dengan menggunakan media telekonferensi, video konferensi atau sarana media elektronik lainnya.

\footnotetext{
F. E. Sumarningsih, Peraturan Jabatan Notaris. (Semarang : Diktat Kuliah Studi Magister Kenotariatan Fakultas Hukum Universitas Diponegoro, 2017), 7.

9 A.A. Andi Prajitno, Op. cit., 84-85.

10 G.H.S. Lumban Tobing, Peraturan Jabatan Notaris. (Jakarta : Erlangga, 1999), 54.
} 
Kosmik Hukum Vol. 21 No. 2 (2021): 105-114

E-ISSN: 2655-9242 | P-ISSN: 1411-9781

DOI: $10.30595 /$ kosmikhukum.v21i2.10283

Agar e-RUPS dapat dilaksanakan, maka penting terlebih dahulu mengetahui siapa saja pengguna e-RUPS, pasal 1 angka (10) POJK Nomor 16/POJK.04/2020 menyebutkan bahwa pengguna e-RUPS dibatasi hanya untuk Perusahaan Terbuka, Partisipan, biro administrasi efek, pemegang saham dan pihak lain yang ditetapkan oleh Penyedia e-RUPS. Selain itu, untuk menyelenggarakan e-RUPS maka terlebih dahulu harus memenuhi persyaratan kuorum dan persyaratan pengambilan keputusan sebagaimana diatur dalam UUPT dan anggaran dasar perseroan. Pelaksanaan e-RUPS bisa diselenggarakan dengan menggunakan e-RUPS yang disediakan oleh Penyedia e-RUPS atau sistem yang disediakan oleh Perusahaan Terbuka dan dilaksanakan dalam wilayah Republik Indonesia. Penyedia e-RUPS sendiri yaitu Lembaga Penyimpanan dan Penyelesaian yang ditunjuk Otoritas Jasa Keuangan (OJK) atau Pihak lain yang disetujui OJK ${ }^{11}$.

Agar e-RUPS dapat terselenggara dengan baik dan lancar, maka penting untuk memperhatikan tata cara pelaksanaan e-RUPS yang diatur dalam ketentuan POJK Nomor 16/POJK.04/2020, sebagai berikut:12 "Pertama, Rencana RUPS secara elektronik harus dinyatakan dalam pemberitahuan agenda kepada Otoritas Jasa Keuangan (OJK), pengumuman dan pemanggilan RUPS. Kedua, RUPS fisik tetap diadakan dengan dihadiri pimpinan RUPS, 1 anggota Direksi dan/atau Dewan Komisaris dan profesi penunjang pasar modal yang membantu RUPS. Ketiga, Pemegang saham atau penerima kuasa dapat hadir fisik secara terbatas dengan prinsip first in first served. Keempat, Pemberian suara (termasuk perubahan dan pencabutannya) dapat dilakukan setelah pemanggilan RUPS sampai dengan pembukaan masing-masing mata acara yang memerlukan pemungutan suara dalam RUPS, namun penyedia e-RUPS wajib merahasiakan suara yang telah diberikan sampai pada saat perhitungan suara. Kelima, Pemegang saham dengan hak suara yang sah yang telah hadir secara elektronik, namun tidak menggunakan hak suaranya atau abstain, dianggap sah menghadiri RUPS dan memberikan suara yang sama dengan suara mayoritas pemegang saham yang memberikan suara dengan menambahkan suara dimaksud pada suara mayoritas pemegang saham."

Berdasarkan pernyataan diatas, maka dapat disimpulkan bahwa pelasanaan e-RUPS tidak seluruhnya dilakukan secara elektronik, melainkan terdapat beberapa ketentuan yang mengharuskan perwakilan dari masing-masing organ perusahaan untuk hadir secara fisik. Hal tersebut sangat penting diketahui oleh para penyelenggara e-RUPS. Selama penyelanggaraan eRUPS, sesuai ketentuan Pasal 77 ayat (4) menerangkan bahwa "Setiap penyelenggaran e-RUPS harus dibuatkan risalah rapat yang disetujui dan ditandatangani oleh semua peserta RUPS". Berdasarkan penjelasan pasal tersebut frasa "disetujui" dan "ditandatangani" dapat dilakukan secara fisik dan secara elektronik. Mengenai tanda tangan yang diberikan oleh para peserta eRUPS pada umumnya berupa tanda tangan digital (digital signature) karena hal tersebut paling memungkinkan dibandingkan tanda tangan fisik. Karena dalam ketentuan pasal 77 ayat (4) UUJN mengharuskan seluruh peserta RUPS menyetujui dan menadatangani risalah RUPS tersebut.

Jika melihat ketentuan pasal 90 ayat (1) UUPT, penandatanganan risalah RUPS tidak harus dilakukan oleh seluruh peserta RUPS, melainkan dapat diwakili oleh ketua rapat dan paling sedikit 1 (satu) orang pemegang saham yang ditunjuk dari dan oleh peserta RUPS. Hal tersebut dapat berlaku pula untuk penandatanganan pada risalah rapat e-RUPS.

Dalam ketentuan UUPT Pasal 77 mengatur mengenai Risalah Rapat RUPS yang diperkenankan dibuat secara notariil atau di bawah tangan (onderhand acta). Dibuat secara notariil maksutnya dibuat oleh Notaris agar risalah rapat tersebut menjadi akta autentik sebagaimana dijelaskan dalam pasal 1868 KUHPerdata. Sedangkan Risalah Rapat RUPS yang dibuat di bawah tangan merupakan risalah rapat yang dibuat tanpa melalui pejabat umum

\footnotetext{
11 Otoritas Jasa Keuangan, Ringkasan POJK tentang Pelaksanaan Rapat Umum Pemegang Saham Perusahaan Terbuka Secara Elektronik, dikutip dari laman :

https://www.ojk.go.id/id/regulasi/Documents/Pages/Pelaksanaan-Rapat-Umum-Pemegang-SahamPerusahaan-Terbuka-Secara-Elektronik--/Ringkasan\%20pojk\%2016.pdf

12 Ikhsan Lubis, RUPS Elektronik, dikutip dari laman : https://medianotaris.com/rups_elektronik_berita690.html
} 
seperti notaris dan formatnya tidak diatur secara spesifik dalam peraturan perundangundangan. ${ }^{13}$ Kekuatan pembuktian masing-masing akta tersebut berbeda. Akta notariil memiliki kedudukan tertinggi sebagai alat bukti dalam hukum perdata dari pada surat di bawah tangan ataupun alat bukti lainnya. ${ }^{14}$

Menurut Andi Prajitno15, untuk RUPS yang dibuat dibawah tangan diperbolehkan menggunakan media elektronik melalui teleconference bagi peserta rapat yang tidak hadir di tempat secara fisik. Meskipun peserta rapat hanya mengikuti rapat secara daring, mereka dapat memberikan pendapat dan menyatakan setuju atau tidak setuju. Hasil keputusan rapat tersebut mempunyai kepastian hukum yang mengikat, keabsahan tersebut berdasarkan UUPT pasal 77, UU ITE pasal 5 dan UU Dokumen Perusahaan. Pasal 1 ayat (2) UU Dokumen Perusahaan menerangkan bahwa :

"Dokumen perusahaan adalah data, catatan, dan atau keterangan yang dibuat dan atau diterima oleh perusahaan dalam rangka pelaksanaan kegiatannya, baik tertulis di atas kertas atau sarana lain maupun rekaman dalam bentuk corak apa pun yang dapat dilihat, dibaca, dan didengar."

Jika ditinjau berdasarkan ruang lingkup data dalam dokumen perusahaan tersebut, "data rekaman dalam bentuk bukan kertas juga diakui sebagai dokumen, sehingga data hasil RUPS yang merupakan dokumen rekaman elektronik diakui keabsahannya". ${ }^{16}$ Hal tersebut diperkuat kembali dalam ketentuan pasal 5 UU ITE yang mengakui akan eksistensi data atau dokumen elektronik sehingga penyelenggaraan e-RUPS beserta hasil rapatnya sah di mata hukum.

Akan tetapi, untuk risalah rapat e-RUPS telah diatur ketentuannya di dalam POJK Nomor 16/POJK.04/2020 pasal 12 ayat (1) yang berbunyi "Risalah RUPS secara elektronik wajib dibuat dalam bentuk akta notariil oleh notaris yang terdaftar di Otoritas Jasa Keuangan tanpa memerlukan tanda tangan dari para peserta RUPS". Selanjutnya dalam angka (2) Penyedia e-RUPS wajib menyerahkan kepada notaris salinan cetakan yang memuat paling sedikit:

1. Daftar pemegang saham yang hadir secara elektronik;

2. Daftar pemegang saham yang memberikan kuasa secara elektronik;

3. Rekapitulasi kuorum kehadiran dan kuoru keputusan; dan

4. Transkrip rekaman seluruh interaksi dalam RUPS secara elektronik untuk dilekatkan pada minut risalah

Jika menelaah ketentuan pasal diatas, maka terdapat dua kemungkinan, yaitu notaris turut hadir dalam penyelenggaraan e-RUPS dan notaris hanya menerima PKR dari notulen rapat yang telah disahkan oleh pimpinan rapat.

\section{Akibat Hukum Pembacaan dan Penandatanganan Akta Notariil e-RUPS secara Elektronik}

Dalam praktek penyelenggaraan e-RUPS, ternyata menimbulkan berbagai implikasi yuridis dalam implementasinya, khususnya mengenai ketentuan Pasal 12 POJK Nomor 16/POJK.04/2020 bahwa "risalah RUPS secara elektronik wajib dibuat dalam bentuk akta notariil oleh Notaris yang terdaftar di Otoritas Jasa Keuangan tanpa memerlukan tanda tangan dari peserta RUPS." Menurut Ikhsan Lubis,Notaris dalam menjalankan tugas jabatannya terkait dengan pembuatan akta otentik terikat kepada persyaratan formalitas pembuatan akta menurut bentuk dan tatacara yang ditetapkan UUJN yang diatur berdasarkan ketentuan Pasal 1 angka 7 UUJN. ${ }^{17}$

Berdasarkan pasal 16 ayat (1) huruf c UUJN, bahwa "notaris dalam melaksanakan jabatannya terikat dengan kewajiban untuk melekatkan surat dan dokumen serta sidik jari penghadap pada minuta akta." Selain itu, ketentuan Pasal 16 Ayat (1) huruf m juga menjelaskan tentang kewajiban Notaris, yaitu : "Dalam menjalankan jabatannya, Notaris wajib

\footnotetext{
13 Habib Adjie, “Konsep Notaris Mayantara Menghadapi TantanganPersaingan Global”, Jurnal Hukum Respublica, Vol. 16 No. 2 (2017), 201-218

14 M. Natsir Aswani, Hukum Pembuktian Perkara Perdata di Indonesia, (Yogyakarta: UII Press, 2013), 34.

15 A.A. Andi Prajitno, Op.cit, 23.

16 Amelia Sri Kusuma Dewi, Loc. Cit.

17 Ikhsan Lubis, Loc. cit
} 
Kosmik Hukum Vol. 21 No. 2 (2021): 105-114

E-ISSN: 2655-9242 | P-ISSN: 1411-9781

DOI: $10.30595 /$ kosmikhukum.v21i2.10283

membacakan Akta di hadapan penghadap dengan dihadiri oleh paling sedikit 2 (dua) orang saksi, atau 4 (empat) orang saksi khusus untuk pembuatan Akta wasiat di bawah tangan, dan ditandatangani pada saat itu juga oleh penghadap, saksi, dan Notaris." Penjelasan dari pasal tersebut menerangkan bahwa harus hadir secara fisik dan akta harus ditandatangani di depan penghadap dan saksi. Dalam ketentuan lain disebutkan bahwa terdapat pengecualian mengenai kewajiban notaris untuk membacakan akta. Hal tersebut diatur pada pasal 16 ayat (7) yang berbunyi : "Pembacaan Akta sebagaimana dimaksud pada ayat (1) huruf m tidak wajib dilakukan, jika penghadap menghendaki agar Akta tidak dibacakan karena penghadap telah membaca sendiri, mengetahui, dan memahami isinya, dengan ketentuan bahwa hal tersebut dinyatakan dalam penutup Akta serta pada setiap halaman Minuta Akta diparaf oleh penghadap, saksi, dan Notaris".

Pada ketentuan pasal 16 ayat (8) UUJN ditegaskan bahwa "Ketentuan sebagaimana dimaksud pada ayat (7) dikecualikan terhadap pembacaan kepala Akta, komparasi, penjelasan pokok Akta secara singkat dan jelas, serta penutup Akta." Selanjutnya substansi pasal 16 ayat (9) menegaskan bahwa "apabila salah satu syarat sebagaimana dimaksud pada ayat (1) huruf $\mathrm{m}$ dan ayat (7) tidak dipenuhi, Akta yang bersangkutan hanya mempunyai kekuatan pembuktian sebagai akta di bawah tangan, dan berdasarkan ketentuan Pasal 16 Ayat (10) Ketentuan sebagaimana dimaksud pada ayat (9) tidak berlaku untuk pembuatan Akta wasiat."

Menurut Ikhsan Lubis, "Konstruksi Yuridis yang dipergunakan UUJN lebih bersifat imperatif terkait dengan kewajiban hukum dalam melaksanakan tugas jabatan Notaris". ${ }^{18}$ Akibat pelanggaran hukum dalam menjalankan tugas jabatannya, maka berdasarkan ketentuan Pasal 16 Ayat (11), "Notaris yang melanggar ketentuan sebagaimana dimaksud pada ayat (1) huruf a sampai dengan huruf 1 dapat dikenai sanksi berupa":

1. Peringatan tertulis;

2. Pemberhentian sementara;

3. Pemberhentian dengan hormat; atau

4. Pemberhentian dengan tidak hormat.

Selain mendapat sanksi sebagaimana tersebut diatas, apabila notaris juga melanggar ketentuan Pasal 16 ayat (1) huruf j bisa menjadi alasan bagi pihak mengalami kerugian untuk menuntut penggantian biaya, ganti rugi, dan bunga kepada Notaris.

Meskipun notaris terikat oleh UUJN, akan tetapi terdapat aturan yang khusus mengatur penyelenggaraan e-RUPS dan Risalah rapatnya yaitu POJK Nomor 16/POJK.04/2020. Yang menjadi pembahasan penting dalam topik ini adalah pembuatan risalah rapat e-RUPS yang harus dibuat dalam bentuk akta notariil. Sebagaimana penjelasan pada sub-bab sebelumnya bahwa terdapat dua cara untuk membuat akta otentik pada pelaksanaan RUPS : yakni (1) notaris turut serta hadir dalam e-RUPS dengan membuat akta berita acara rapat, atau (2) notulis menyerankan PKR ke notaris untuk dibuat dalam bentuk akta otentik. ${ }^{19}$

Apabila notaris turut serta hadir dalam e-RUPS, yang menjadi permasalahan yaitu terkait pembacaan akta secara elektronik mengingat e-RUPS penyelenggaraannya berbasis elektronik. Sedangkan dalam ketentuan KUHPerdata dan UUJN, notaris wajib membacakan akta secara fisik dihadapan penghadap dan saksi. Akan tetapi, dalam Pasal 12 POJK tersebut diatas menjelaskan bahwa penandatanganan hanya dilakukan oleh notaris dan saksi-saksi saja. Dari ketentuan tersebut maka penulis menyimpulkan bahwa pembacaan akta berita acara secara elektronik dapat dilaksanakan secara elektronik dengan ketentuan bahwa akta ditandatangani notaris dan saksi-saksi saja. Sehingga otentitas dari akta tersebut (Relass Acta) tetap memenuhi unsur akta otentik sebagaimana dimaksud dalam Pasal 1868 KUHPerdata. Yang menjadi masalah ketika notaris dalam membuat akta berita acara dengan menggunakan tanda tangan elektronik, maka hal ini bertentangan dengan Pasal 16 ayat (1) huruf m UUJN dan Pasal 5 ayat (4) huruf a UU ITE. Meskipun terdapat konsep cyber notary dalam bidang kenotariatan yang termuat dalam ketentuan pasal 15 ayat (3), namun ketentuan tersebut hanya sebatas

18 Ibid.

19 C. W. Widiyawati, "Akta Notaris Dalam Pelaksanaan Rapat Umum Pemegang Saham Perseroan Terbatas Melalui Telekonferensi", Jurnal Repertorium, Vol. 3 No. 2 (2020), 50-57 
mensertifikasi transaksi elektronik dan tidak ada regulasi yang secara eksplisit memberikan wewenang kepada notaris untuk melegalkan tanda tangan elektronik dalam pembuatan aktanya. Hal tersebut akan berakibat hilangnya otentitasnya sebagai akta otentik.

Selanjutnya mengenai cara yang kedua, yaitu notaris membuat Akta PKR. Akta tersebut dibuat dihadapan notaris berdasarkan atas notulensi e-RUPS yang dibuat secara di bawah tangan, kemudian dibawa ke Notaris oleh salah seorang/beberapa kuasa notulen e-RUPS yang dibuat oleh para pemegang saham. ${ }^{20}$ Sehingga akta tersebut merupakan bentuk akta partij karena kuasa notulen e-RUPS menghadap ke notaris dan notaris hanya mencatatkan kesepakatan atau kehendak para pihak dalam akta. Berdasarkan cara tersebut, maka otentitas dari akta tersebut memenuhi ketentuan pasal 1868 KUHPerdata sebagai akta otentik. Hal ini sependapat dengan Andi Prajitno yang mengatakan bahwa sesuai dengan UUJN dan UU ITE hanya e-RUPS yang dibuat di bawah tangan saja yang boleh menggunakan media elektronik yang kemudian ditindaklanjuti dengan menotariilkan hasil dari RUPS yang berupa PKR di bawah tangan tersebut.

Dalam melaksanakan kewenangan Notaris dalam membuat Akta PKR harus mememenuhi syarat-syarat kewenangan notaris yang lain diantaranya:21

1) "Penghadap bukan merupakan pihak yang dilarang oleh undang-undang, diantaranya isteri atau suami Notaris yang membuat akta tersebut, memiliki hubungan darah atau semenda dengan Notaris, serta harus dewasa, dikenal oleh notaris atau diperkenalkan oleh 2 (dua) orang saksi atau 2 (dua) orang penghadap lainnya, dan cakap melakukan perbuatan hukum;"

2) "Akta PKR dibuat di dalam wilayah jabatan notaris yang bersangkutan;"

3) "Akta PKR dibuat oleh notaris yang sedang melaksanakan jabatannya. Notaris dalam menjalankan masa jabatannya harus dalam keadaan aktif, artinya tidak dalam keadaan cuti atau diberhentikan sementara."

Apabila risalah e-RUPS tidak dibuat oleh atau dihadapan notaris melainkan hanya dibuat di bawah tangan saja, maka hal tersebut melanggar ketentuan POJK Nomor 16/POJK.04/2020 pasal 12 ayat (1), (2) dan (3). Terdapat sanksi administratif bagi pelanggar ketentuan tersebut, yang termuat dalam ketentuan pasal 13 POJK di atas yaitu : peringatan tertulis; denda yaitu kewajiban untuk membayar sejumlah uang tertentu; pembatasan kegiatan usaha; pembekuan kegiatan usaha; pencabutan izin usaha; pembatalan persetujuan; dan/atau pembatalan pendaftaran.

Jika menelaah regulasi diatas, maka terdapat implikasi hukum yang dapat ditimbulkan yaitu apabila notaris membuat risalah rapat e-RUPS tanpa menelaah aturan hukum yang berlaku, kemudian membacakan serta menandatangani akta tersebut secara elektronik, maka konsukensinya dapat berimbas pada kekuatan hukumnya yaitu setara dengan surat dibawah tangan.

\section{Penutup}

Berdasarkan regulasi terbaru yaitu POJK 16/POJK.04/2020, risalah rapat e-RUPS wajib dibuat dalam bentuk akta notariil yang hanya ditandatangani oleh notaris dan saksi-saksi saja secara fisik. Maka dapat disimpulkan bahwa akta tersebut dapat dibuat dalam 2 bentuk, yaitu : pertama, dibuat dalam bentuk Akta Berita Acara (Relaas Acte) oleh Notaris yang turut serta hadir sepanjang jalannya e-RUPS. Berdasarkan ketentuan tersebut Notaris mempunyai kewenangan untuk membacakan akta, maka pembacaan dapat dilakukan secara elektronik khusus pada lingkup penyelengaraan e-RUPS saja, sedangkan mengenai tanda tangan tetap harus dilakukan secara konvensional oleh notaris dan saksi-saksi. Kedua, risalah akta e-RUPS dibuat berdasarkan penyerahan PKR ke notaris maka pembacaan dan penandatangan

20 Yahya Agung Putra, Annalisa Yahanan, Agus Trisaka, “Video Konferensi dalam Rapat Umum Pemegang Saham Berdasarkan Pasal 77 Undang-Undang Perseroan Terbatas", Jurnal Repertorium, Vol. 8 No. 1 (2019), 35-50.

21 Wardani Rizkianti, "Akta Otentik Rapat Umum Pemegang Saham (RUPS) Melalui Media Telekonferensi (Mekanisme Pembuatan Dan Kekuatan Pembuktiannya)", Jurnal Yuridis, Vol. 3 No. 1 (2016), 84-98. 
Kosmik Hukum Vol. 21 No. 2 (2021): 105-114

E-ISSN: 2655-9242 | P-ISSN: 1411-9781

DOI: $10.30595 /$ kosmikhukum.v21i2.10283

dilakukan secara fisik, karena akta tersebut berbentuk akta partij yang mengharuskan adanya kehadiran secara lahiriah.

Jika notaris dalam membuat aktanya ditandatangani secara elektronik, maka berakibat pada hilangnya unsur otentitas dari suatu akta otentik sebagaimana ketentuan pasal 1868 KUHPerdata. Sebab aturan mengenai penandatanganan akta notaris secara elektronik masih terdapat kekosongan hukum dan eksistensinya belum diakui oleh KUHPerdata, UUJN, UU ITE dan POJK. Apabila adanya implikasi yuridis tersebut tersebut membuat enggan penyelenggara e-RUPS untuk membuat risalah rapat dalam bentuk otentik, maka terdapat sanksi administratif baginya sebagaimana di atur dalam Pasal 13 POJK 2020 tersebut di atas.

\section{Daftar Pustaka}

Adjie, Habib. "Konsep Notaris Mayantara Menghadapi Tantangan Persaingan Global", Jurnal Hukum Respublica, Vol. 16 No. 2 (2017), 201-218

Hukum Notarias Indonesia: Tafsir Tematik Terhadap UU No. 30 Tahun 2004 tentang Jabatan Notaris. Bandung : Refika Aditama, 2011.

Aswani, M. Natsir. Hukum Pembuktian Perkara Perdata di Indonesia. Yogyakarta: UII Press, 2013

Dewi, Amelia Sri Kusuma. "Penyelenggaraan RUPS melalui Media Elektronik terkait Kewajiban Notaris Melekatkan Sidik Jari Penghadap". Jurnal Arena Hukum, Vol. 8 No. 1 (2015), 108-126

Lubis, Ikhsan. "RUPS Elektronik" dikutip dari laman : https://medianotaris.com/rups_elektronik_berita690.html ; diakses pada 30 Maret 2021

Lumban Tobing, G.H.S, Peraturan Jabatan Notaris. Jakarta : Erlangga, 1999

Moechthar, Oemar, Dasar-Dasat Teknik Pembuatan Akta, Surabaya : Airlangga University Press, 2017

Otoritas Jasa Keuangan (OJK), Ringkasan POJK tentang Pelaksanaan Rapat Umum Pemegang Saham Perusahaan Terbuka Secara Elektronik, dikutip dari laman: https://www.ojk.go.id/id/regulasi/Documents/Pages/Pelaksanaan-Rapat-UmumPemegang-Saham-Perusahaan-Terbuka-Secara-Elektronik-/Ringkasan\%20pojk\%2016.pdf ; diakses pada 30 Maret 2021

Prajitno, A.A. Andi, Pengetahuan Praktis tentang Apa dan Siapa Notaris di Indonesia? Sesuai UUJN Nomor 2 Tahun 2014, Surabaya : Putra Media Nusantara, 2018

Putra, Yahya Agung., Annalisa Yahanan, Agus Trisaka, "Video Konferensi dalam Rapat Umum Pemegang Saham Berdasarkan Pasal 77 Undang-Undang Perseroan Terbatas, Jurnal Repertorium, Vol. 8 No. 1 (2019), 35-50.

Rizkianti, Wardani. "Akta Otentik Rapat Umum Pemegang Saham (RUPS) Melalui Media Telekonferensi (Mekanisme Pembuatan Dan Kekuatan Pembuktiannya)", Jurnal Yuridis, Vol. 3 No. 1 (2016), 84-98.

Sumarningsih, F. E, Peraturan Jabatan Notaris. Diktat Kuliah. Semarang: Studi Magister Kenotariatan, Fakultas Hukum Universitas Diponegoro, 2001.

Widiyawati, C.W. "Akta Notaris Dalam Pelaksanaan Rapat Umum Pemegang Sham Perseroan Terbatas Melalui Telekonferensi", Jurnal Repertorium, Vol. 3 No. 2 (2020), 50-57 